\title{
In Vivo Nitrogen Metabolism in Ornithine Transcarbamylase Deficiency
}

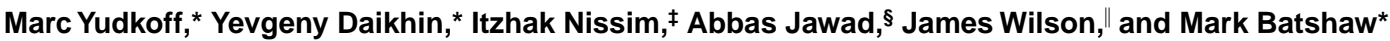 \\ $*$ Division of Child Development, ${ }^{\ddagger}$ Division of Metabolism, and ${ }^{\S}$ Division of Biostatistics, Children’s Hospital of Philadelphia, Children’s

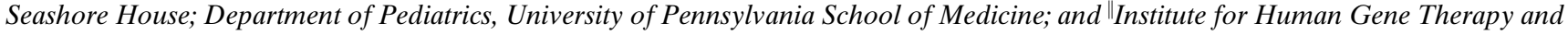 \\ Department of Molecular and Cellular Engineering and Department of Medicine of the University of Pennsylvania School of Medicine \\ and the Wistar Institute, Philadelphia, Pennsylvania 19104
}

\begin{abstract}
We developed a new technique that monitors metabolic competency in female heterozygotes for ornithine transcarbamylase deficiency (OTCD). The method uses mass spectrometry to measure conversion of ${ }^{15} \mathrm{NH}_{4} \mathrm{Cl}$ to $\left[{ }^{15} \mathrm{~N}\right]$ urea and $\left[5-{ }^{15} \mathrm{~N}\right]$ glutamine following an oral load of ${ }^{15} \mathrm{NH}_{4} \mathrm{Cl}$. We found that heterozygotes converted significantly less $\mathrm{NH}_{3}$ nitrogen to urea, with this difference being particularly obvious for symptomatic carriers, in whom the blood $\left[{ }^{15} \mathrm{~N}\right]$ urea concentration (mM) was significantly less than control values at most time points. The blood concentration of $\left[5-{ }^{15} \mathrm{~N}\right]-$ glutamine $(\mu \mathrm{M})$ was significantly higher in both asymptomatic and symptomatic heterozygotes than it was in the control subjects. The administration of a test dose of sodium phenylbutyrate to the control group did not affect the rate of $\left[{ }^{15} \mathrm{~N}\right]$ urea formation. We conclude: (a) This test effectively monitors in vivo $\mathrm{N}$ metabolism and might obviate the need for liver biopsy to measure enzyme activity in OTCD; (b) Asymptomatic OTCD carriers form urea at a normal rate, indicating that ureagenesis can be competent even though enzyme activity is below normal; (c) Although ostensibly asymptomatic OTCD carriers form urea at a normal rate, their nitrogen metabolism is still abnormal, as reflected in their increased production of $\left[5-{ }^{15} \mathrm{~N}\right]$ glutamine; and $(d)$ This new test may be important for monitoring the efficacy of novel treatments for OTCD, e.g., liver transplantation and gene therapy. (J. Clin. Invest. 1996. 98:2167-2173.) Key words: ureagenesis • stable isotopes $\bullet$ mass spectrometry
\end{abstract}

\section{Introduction}

The relationship between in vitro enzyme activity and in vivo metabolic flux in patients with inborn errors of metabolism is not always straightforward. Even individuals with markedly reduced enzyme activity may display a surprisingly intact degree of flux through the metabolic pathway. Thus, a recent study showed that the in vivo rate of $\left[{ }^{13} \mathrm{C}\right]$ leucine oxidation in children with branched-chain ketoacid decarboxylase deficiency (maple syrup urine disease) exceeded the in vitro rate

Address correspondence to Marc Yudkoff, M.D., Children's Hospital of Philadelphia, 1 Children's Center, Abramson Building 510, Philadelphia, PA 19104-4318. Phone: 215-590-3412; FAX: 215-590-3779; E-mail: myudkoff@mail.med.upenn.edu

Received for publication 7 May 1996 and accepted in revised form 20 August 1996.

J. Clin. Invest.

(C) The American Society for Clinical Investigation, Inc. 0021-9738/96/11/2167/07 \$2.00

Volume 98, Number 9, November 1996, 2167-2173 as measured in cultured skin fibroblasts (1). Similarly, residual activity of propionyl-CoA carboxylase reflects neither disease severity nor clinical outcome in patients with propionic acidemia (2). The relative preservation of metabolic flux suggests that, for most enzymes, the "normal" level of activity greatly exceeds that necessary to maintain metabolic integrity. In addition, metabolic flux depends on processes other than enzymatic activity, e.g., cell transport, compartmentation of enzyme activities and inhibitors and stimulators of flux.

The relationship between genotype and phenotype is especially complex for ornithine transcarbamylase deficiency (OTCD),${ }^{1}$ an inherited disorder of the urea cycle that involves diminished conversion of carbamyl phosphate to citrulline. Untreated males with the classic variant of this X-linked enzymopathy characteristically die with fulminant hyperammonemic coma during the first week of life. Affected females manifest a milder syndrome because of random inactivation of the $\mathrm{X}$ chromosome and consequent variable expression of hepatic enzyme activity (3). Most female carriers are clinically silent. Some manifest mild symptoms, e.g., headache or nausea, following a large protein intake or an intercurrent illness. About $10 \%$ of carriers develop more severe symptoms, e.g., lethargy or encephalopathy, that are attributable to compromised urea synthesis (4).

We have developed a new test that measures ureagenesis in vivo. The procedure involves the conversion of an oral load of the stable isotope ${ }^{15} \mathrm{NH}_{4} \mathrm{Cl}$ to $\left[{ }^{15} \mathrm{~N}\right]$ urea, which is quantified with gas chromatography-mass spectrometry. Stable isotopes have been used previously for the in vivo determination of ureagenesis (5-9), but this technique has not been applied to the study of OTCD heterozygotes.

We have administered the test to a group of obligate female heterozygotes. The results indicate that clinically asymptomatic carriers convert ammonia to urea at a normal rate, even though they have less enzyme activity than controls. In contrast, ureagenesis in symptomatic heterozygotes was significantly below normal. Although ureagenesis was normal in asymptomatic heterozygotes, their rate of $\left[5-{ }^{15} \mathrm{~N}\right]$ glutamine production, like that of symptomatic heterozygotes, exceeded the control value.

The new test is safe and simple. It can be administered sequentially to the same individual. Thus, it ought to be a useful tool with which to assess the efficacy of therapeutic interventions, e.g., gene therapy and liver transplantation (10-14).

\section{Methods}

Materials. ${ }^{15} \mathrm{NH}_{4} \mathrm{Cl}$ (98 atom percent excess) was purchased from Cambridge Isotope Laboratories (Woburn, MA). Reagents for de-

1. Abbreviations used in this paper: OTCD, ornithine transcarbamylase. 
rivatization of urea and amino acids were from Pierce Chemical Co. (Rockford, IL). Ion-exchange resins were from Bio-Rad (Richmond, CA).

Subjects. Subjects with one or more of the following criteria were considered to be heterozygotes for OTCD: (a) A history of having more than one affected child; $(b)$ having a single affected child as well as a mother and/or sister who also was affected or who had an affected child; $(c)$ a positive allopurinol loading test (15); and/or $(d)$ a demonstrable mutation in the OTC gene (16). A control group of comparable age was drawn from females who had no personal or familial history to suggest OTCD or other inborn error of metabolism.

Asymptomatic heterozygotes $(n=6)$ were defined as females who had no protein intolerance or other symptoms of hyperammonemia. Symptomatic heterozygotes $(n=8)$ included those women who had a frank history of protein intolerance or hyperammonemia or who had sustained neurologic injury, e.g., mental retardation, because of OTCD.

Procedure. After an overnight fast, all subjects were brought to the out-patient facility of the Clinical Research Center of the Children's Hospital of Philadelphia. Symptomatic patients with OTCD who were being treated with sodium phenylbutyrate (17) took their usual morning dose, but no other medications. After obtaining baseline samples of blood and urine, each subject ingested by mouth 25.9 mmol $(\sim 0.37 \mathrm{mmol} / \mathrm{kg} ; 20 \mathrm{mg} / \mathrm{kg})$ of ${ }^{15} \mathrm{NH}_{4} \mathrm{Cl}$ (98 atom percent excess) dissolved in $125 \mathrm{ml}$ of chilled water. A non-caloric flavoring was added to the solution to improve palatability. Blood (5 $\mathrm{ml}$ in a heparinized tube) was sampled from an indwelling venous catheter at 0 , $30,60,90,120,180$, and 240 min after ingestion of the labelled ammonia). It was placed in a heparinized glass tube, gently mixed and centrifuged to separate the plasma, which was kept frozen $\left(-40^{\circ} \mathrm{C}\right)$ until it was analyzed. The study was concluded after $4 \mathrm{~h}$.

Informed consent was obtained from each subject or, when appropriate, from both the subject and his or her parents. This study was reviewed and approved by the Committee for the Protection of Human Subjects of the Children's Hospital of Philadelphia.

The putative effect of sodium phenylbutyrate on the testing procedure was examined by repeating the ${ }^{15} \mathrm{NH}_{4} \mathrm{Cl}$ loading study in four control subjects who took a single dose of sodium phenylbutyrate at $30 \mathrm{~min}$ before isotope administration. The remainder of the study was performed in a manner identical to the original protocol.

Analytic methods. Plasma was separated by centrifugation of 100 $\mu l$ of heparinized blood. It was treated with an equal volume of $10 \%$ trichloroacetic acid. The precipitated proteins were removed by centrifugation. Plasma lipids and the trichloroacetic acid were removed by extraction $(4 \times)$ with $1.5 \mathrm{ml}$ of ethyl ether. After drying the sample under nitrogen, the t-butyldimethylsilyl (TBDMS) derivatives of both urea and glutamine were prepared (18) with acetonitrile as solvent. The final volume was $100 \mu \mathrm{l}$.

Mass spectrometry was performed on a Hewlett-Packard MSD GC-MS system. The following ion ratios were used: glutamine $\mathrm{m} / \mathrm{z}$ $432 / 431$ and urea $\mathrm{m} / \mathrm{z} 232 / 231$. The electron multiplier was set to $\sim 2000 \mathrm{~V}$, the filament potential to $70 \mathrm{eV}$, source temperature and transfer line both were at $280^{\circ} \mathrm{C}$ and the injector at $250^{\circ} \mathrm{C}$. The temperature program was $120^{\circ} \mathrm{C}$ for $3 \mathrm{~min}$ and then $8^{\circ} \mathrm{C} / \mathrm{min}$ until $280 \mathrm{de}-$ grees. The column was a $12 \mathrm{M} \times 0.32 \mathrm{~mm}$ Ultra- 2 capillary from Hewlett-Packard. Calibration curves for $\left[{ }^{15} \mathrm{~N}\right]$ glutamine and $\left[{ }^{15} \mathrm{~N}\right]$ urea were run on a weekly basis to assure linearity of response for the $(\mathrm{M}+1) /(\mathrm{M})$ ratio.

In order to be certain that all ${ }^{15} \mathrm{~N}$ was resident in the amide rather than the amino group of glutamine, representative samples $(0.25 \mathrm{ml})$ of plasma were added to an equal volume of imidazole buffer (50 $\mathrm{mM} ; \mathrm{pH} 8.0)$ and passed over a column $(0.7 \mathrm{ml})$ of AG-1 resin (X-8; 100-200 mesh) in the $\mathrm{Cl}^{-}$form. This procedure separated glutamate, which bound to the resin, from glutamine, which was recovered in the initial eluate and a $1 \mathrm{ml}$ water wash. The glutamine fraction was adjusted to $1 \mathrm{~N} \mathrm{HCl}$ and heated for $90 \mathrm{~min}$ at $100^{\circ} \mathrm{C}$ in order to hydrolyze all glutamine to glutamate. After taking this fraction to dryness, the tri-TBDMS derivative of glutamate was prepared. Labeling of $\left[{ }^{15} \mathrm{~N}\right.$ ]glutamate was determined by monitoring the $\mathrm{m} / \mathrm{z} 433 / 432$ ratio (18). In no instance was ${ }^{15} \mathrm{~N}$ label present, indicating that all ${ }^{15} \mathrm{~N}$ enrichment of glutamine was resident in the amide $\mathrm{N}$.

The concentration of amino acids was determined by a HPLC method utilizing pre-column derivatization with o-phthalaldehyde and fluorescent detection (19). The internal standard was $\epsilon-\mathrm{NH}_{2}$-caproic acid.

Blood urea was determined with the indophenol-hypochlorite method.

Calculations. Isotopic enrichment (atom percent excess) in a given metabolite was calculated according to Rosenblatt et al. (20). This value represents the incremental label (percent) over baseline. The concentration of labelled $\left[{ }^{15} \mathrm{~N}\right]$ urea $(\mathrm{mM})$ or of $\left[5^{-15} \mathrm{~N}\right]$ glutamine $(\mu \mathrm{M})$ is:

[atom percent excess/100] $\times$

[concentration of either urea $(\mathrm{mM})$ or glutamine $(\mu \mathrm{M})]$.

The conversion of ammonia into urea (percentage of ${ }^{15} \mathrm{NH}_{4} \mathrm{Cl}$ dose) is given by:

$100 \times$ Amount of ${ }^{15} \mathrm{NH}_{4} \mathrm{Cl}$ Load/

$\left(\left[{ }^{15} \mathrm{~N}\right]\right.$ urea $(\mathrm{mM}) \times 0.4 \times$ Weight $\left.(\mathrm{kg}) \times 2\right)$

where the factor 0.4 refers to the urea space, the factor 2 refers to the fact that each molecule of urea includes two atoms of nitrogen, and $\left[{ }^{15} \mathrm{~N}\right]$ urea is the concentration $(\mathrm{mM})$ of singly labeled urea in the blood.

Statistical analysis. For each subject, the appearance of the ${ }^{15} \mathrm{~N}$ label in either blood $\left[{ }^{15} \mathrm{~N}\right]$ urea or $\left[5-{ }^{15} \mathrm{~N}\right]$ glutamine was measured at baseline, 30, 60, 90, 120, and 180 min after ingestion of ${ }^{15} \mathrm{NH}_{4} \mathrm{Cl}$. For each subject the area under the curves was determined with a standard software package (21). The group value was calculated as the mean \pm SEM. Comparisons between groups (control; asymptomatic heterozygotes; symptomatic heterozygotes) were based on differences of means of the areas under the curves using a one-way analysis of variance followed by the Newman-Keuls test for multiple comparisons. When the assumption of homogeneity of variances was not met, a log transformation of the data was done and ANOVA testing was done using the log-transformed variable. Significance was set at $P<$ 0.05 .

The $t$ test for paired data was used to compare the effects of sodium phenylbuytrate on ureagenesis (see above for experimental details).

\section{Results}

Subjects. All subjects (Table I) were female, including controls $(n=9)$, asymptomatic heterozygotes $(n=6)$ and symptomatic heterozygotes $(n=8)$. The sole exception was a 12-yr-old boy with severe, neonatal-onset OTCD who had multiple developmental disabilities. Blood levels of urea and ammonia at baseline and 120 min were similar in both asymptomatic and symptomatic heterozygotes vs controls (Table I). There was no consistent increase of the blood ammonia level following administration of ${ }^{15} \mathrm{NH}_{4} \mathrm{Cl}$. Nor did any OTCD carrier experience clinical symptoms following the ammonia load.

The baseline (T0) plasma glutamine concentration was similar in controls and asymptomatic OTCD heterozygotes, but it was significantly $(P<0.05)$ greater than control in symptomatic heterozygotes and remained elevated at $120 \mathrm{~min}$ after administration of ${ }^{15} \mathrm{NH}_{4} \mathrm{Cl}$ (Table I). In none of the groups did the plasma glutamine value at $2 \mathrm{~h}$ increase significantly relative to baseline. The concentration of glutamine in heterozygotes was more variable than was true of the control population. This reflects the fact that the carriers presumably do not share 
Table I. Description of Patients

\begin{tabular}{|c|c|c|c|c|c|c|c|c|c|}
\hline Group & Age & $\begin{array}{c}{[\mathrm{Gln}]} \\
\mathrm{T} 0\end{array}$ & $\begin{array}{l}{[\mathrm{Gln}]} \\
\mathrm{T} 120\end{array}$ & $\begin{array}{c}{\left[\mathrm{NH}_{3}\right]} \\
\mathrm{T} 0\end{array}$ & $\begin{array}{l}{\left[\mathrm{NH}_{3}\right]} \\
\mathrm{T} 120\end{array}$ & $\begin{array}{l}\text { [Urea] } \\
\text { T0 }\end{array}$ & $\begin{array}{c}{[\text { Urea] }} \\
\text { T120 }\end{array}$ & Symptoms & Treatment \\
\hline A. Controls $(n=9)$ & $30.9 \pm 2.4$ & $285.0 \pm 21.5$ & $274.7 \pm 25.9$ & $25.7 \pm 6.3$ & $35.2 \pm 6.2$ & $4.2 \pm 0.4$ & $4.6 \pm 0.4$ & N/A & N/A \\
\hline \multicolumn{10}{|c|}{ B. Asymptomatic Hetero } \\
\hline Subject 1 & 40 & 378.4 & 383.8 & 7.5 & 11.9 & 6.2 & 5.0 & None & None \\
\hline Subject 2 & 45 & 289.0 & 288.0 & 56.0 & 66.3 & 3.6 & 2.9 & None & None \\
\hline Subject 3 & 44 & 270.0 & 376.0 & 11.2 & 9.5 & 4.2 & 3.7 & None & None \\
\hline Subject 4 & 43 & 514.3 & 429.8 & 16.5 & 59.6 & 4.7 & 4.8 & None & None \\
\hline Subject 5 & 41 & 417.7 & 443.3 & 18.6 & 11.4 & 5.9 & 4.2 & None & None \\
\hline Subject 6 & 28 & 1316.0 & 1138.0 & 39.0 & 34.0 & 4.0 & 3.0 & None & None \\
\hline Mean \pm SEM & $40.2 \pm 4.0$ & $530.9 \pm 161.2$ & $509.8 \pm 127.6$ & $24.8 \pm 7.7$ & $32.1 \pm 10.9$ & $4.8 \pm 0.4$ & $3.9 \pm 0.4$ & & \\
\hline \multicolumn{10}{|c|}{ C. Symptomatic Hetero } \\
\hline Subject 1 & 25 & 425.0 & 428.5 & 9.4 & 22.2 & 5.6 & 5.7 & $\begin{array}{l}\text { Protein intolerance } \\
\text { Protein intolerance; }\end{array}$ & None \\
\hline Subject 2 & 45 & 544.7 & 749.5 & 7.2 & 23.0 & 2.8 & 3.2 & $\begin{array}{c}\text { seizures } \\
\text { Protein intolerance; }\end{array}$ & $\begin{array}{c}\text { None } \\
\text { Benzoate; }\end{array}$ \\
\hline Subject 3 & 17 & 794.8 & 880.2 & 12.4 & 27.3 & 1.8 & 1.2 & $\begin{array}{c}\text { ataxia } \\
\text { Vomiting, lethargy; }\end{array}$ & $\begin{array}{l}\text { citrulline; LPD } \\
\text { Phenylbutyrate. }\end{array}$ \\
\hline Subject 4 & 14 & 345.1 & 353.4 & 20.6 & 41.8 & 3.9 & 5.1 & Mild MR & citrulline; LPD \\
\hline Subject 5 & 43 & 358.2 & 316.2 & 41.1 & 23.9 & 6.4 & 4.8 & $\begin{array}{l}\text { Protein intolerance } \\
\text { Protein intolerance; }\end{array}$ & Citrulline; LPD \\
\hline Subject 6 & 8.6 & 1030.0 & 1197.0 & 20.0 & 44.0 & 1.9 & 1.8 & Mild MR & Benzoate; LPD \\
\hline Subject 7 & 49 & 1124.0 & 1205.0 & ND & 33.0 & 4.9 & 4.9 & Protein intolerance & None \\
\hline Subject 8 & 31 & 1490.0 & 1809.0 & ND & 43.0 & 1.2 & 0.9 & Protein intolerance & None \\
\hline Mean \pm SEM & $29.1 \pm 5.4$ & $764.0 \pm 148.3^{*}$ & $867.3 \pm 183.4^{*}$ & $18.5 \pm 5.1$ & $32.3 \pm 3.3$ & $3.6 \pm 0.7$ & $3.5 \pm 0.7$ & & \\
\hline \multicolumn{10}{|l|}{ D. Neonatal onset } \\
\hline Subject 1 & 12 & 206.5 & 515.5 & 22 & 27 & 1.2 & 0.7 & Profound MR & $\begin{array}{c}\text { Phenylbutyrate, } \\
\text { LPD }\end{array}$ \\
\hline
\end{tabular}

All values are mean \pm SEM. $N D$, not determined; $N / A$, not applicable; $M R$, mental retardation; $L P D$, low protein diet; ${ }^{*} P<0.05$ compared with control. There is no significant difference with respect to baseline blood [glutamine] for asymptomatic vs. symptomatic heterzygotes.

a common mutation of the OTC gene. Levels of glutamine are more variable than those of urea because of the much slower turnover of the latter pool.

Synthesis of ${ }^{15}$ N]urea. Enrichment (atom percent excess) in $\left[{ }^{15} \mathrm{~N}\right]$ urea is illustrated in Fig. 1. After ingestion of ${ }^{15} \mathrm{NH}_{4} \mathrm{Cl}$, labeling in both controls and asymptomatic heterozygotes increased linearly during the first hour, reaching a value of $\sim 5.0$ atom percent excess by $60 \mathrm{~min}$ and remaining at approximately that level for the duration of the study. Labeling of $\left[{ }^{15} \mathrm{~N}\right]$ urea in the symptomatic heterozygotes increased more slowly. The maximal enrichment for the three groups ( \pm SEM) was: $6.2 \pm 0.5$ (control), $5.4 \pm 0.6$ (asymptomatic heterozygotes) and $3.5 \pm 0.4$ (symptomatic heterozygotes). Values for the symptomatic group were significantly $(P<0.05)$ lower than those of the controls or asymptomatic carriers. The latter two groups did not differ from one another.

Cumulative labeling for controls, asymptomatic heterozygotes and symptomatic heterozygotes was (atom percent excess $\times 30 \mathrm{~min} ; \pm \mathrm{SEM}$ ): 1089 $\pm 78,993 \pm 108$, and $637 \pm 85$, respectively. Controls and asymptomatic heterozygotes did not differ from one another but both of these groups had values that were significantly higher than that of symptomatic heterozygotes $(P<0.05)$.
The severely affected male OTCD hemizygote formed very little $\left[{ }^{15} \mathrm{~N}\right]$ urea in comparison with controls. He attained a maximal labelling of 1.4 atom percent excess by 90 min (Fig. 1).

The foregoing data refer to the enrichment of blood urea. In Fig. 2 is shown the absolute concentration of plasma $\left[{ }^{15} \mathrm{~N}\right]$ urea, corresponding to the product/100 of enrichment (atom percent excess) and total plasma urea (mM). For the three groups this parameter reached these maximal values (mM; \pm SEM): 0.279 \pm 0.021 (control), $0.237 \pm 0.027$ (asymptomatic heterozygotes) and $0.128 \pm 0.030$ (symptomatic heterozygotes). The mean maximal value in symptomatic carriers was less $(P<0.05)$ than that of controls or asymptomatic heterozygotes. The latter two groups did not differ from one another.

Mean cumulative $\left[{ }^{15} \mathrm{~N}\right]$ urea synthesis $(\mathrm{mM} \times 30 \mathrm{~min})$ was ( \pm SEM): $44.7 \pm 3.6$ (control), $39.4 \pm 4.2$ (asymptomatic heterozygotes), and $22.5 \pm 5.5$ (symptomatic heterozygotes). The symptomatic group differs significantly $(P<0.05)$ both from controls and from asymptomatic heterozygotes. There is no significant difference for controls vs. asymptomatic heterozygotes.

If we assume a urea distribution space of $\sim 40 \%$ of body weight, then the initial rate of urea synthesis, based on the 


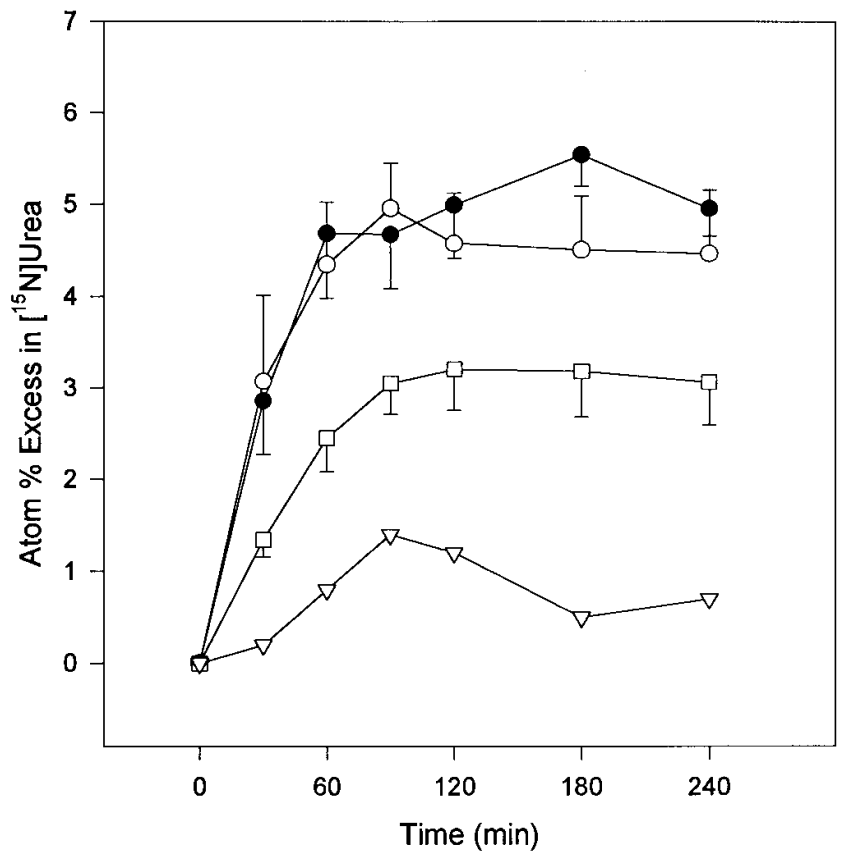

Figure 1. Isotopic Abundance (atom percent excess) in blood $\left[{ }^{15} \mathrm{~N}\right]$ urea (single labeled) after the oral administration of ${ }^{15} \mathrm{NH}_{4} \mathrm{Cl}$ to controls $(n=9)$, asymptomatic OTCD heterozygotes $(n=6)$, symptomatic heterozygotes $(n=8)$ and a hemizygous male with OTCD. Each point is the mean \pm SEM. $(\bullet)$ control, $(\bigcirc)$ asymptomatic heterozygotes, $(\square)$ symptomatic heterozygotes, $(\nabla)$ male hemizygote.

blood $\left[{ }^{15} \mathrm{~N}\right]$ urea concentration at $30 \mathrm{~min}$, was $1.75 \pm 0.41 \mu \mathrm{mol} /$ $\mathrm{kg} / \mathrm{min}$ in the controls and $1.64 \pm 0.42 \mu \mathrm{mol} / \mathrm{kg} / \mathrm{min}$ in asymptomatic heterozygotes $(P<0.05)$. The comparable value in symptomatic heterozygotes was $0.52 \pm 0.13 \mu \mathrm{mol} / \mathrm{kg}$ per min (range $0.16-0.81 \mu \mathrm{mol} / \mathrm{kg}$ per $\mathrm{min})(P=0.05$ compared with control), or about $30 \%$ of the control value. In the male hemizygote this parameter was $0.029 \mu \mathrm{mol} / \mathrm{kg} / \mathrm{min}$, or $<2 \%$ of the control rate.

Synthesis of $\left[5{ }^{15} \mathrm{~N}\right]$ glutamine. The transfer of nitrogen from ${ }^{15} \mathrm{NH}_{3}$ to the amide group of glutamine is shown in Fig. 3, which illustrates labelling (atom percent excess) in plasma [5$\left.{ }^{15} \mathrm{~N}\right]$ glutamine. Labeling increased rapidly over the initial 60 min, declining thereafter. Peak enrichments (atom percent excess) in the three groups were $( \pm$ SEM): $7.0 \pm 1.2$ (control), $12.9 \pm 1.6$ (asymptomatic heterozygotes) and 13.1 \pm 1.1 (symptomatic heterozygotes). For both groups of carriers the values are significantly $(P<0.05)$ higher than control. The carriers did not differ from one another. The ${ }^{15} \mathrm{~N}$ label appeared to disappear more rapidly from the plasma of both groups of heterozygotes than from that of control subjects (Fig. 3).

The cumulative appearance of label in $\left[5^{-15} \mathrm{~N}\right]$ glutamine (atom percent excess $\times 30 \mathrm{~min}$ ) was $( \pm$ SEM): $1000 \pm 162$ (control), 1880 \pm 275 (asymptomatic heterozygotes) and 1940 \pm 210 (symptomatic heterozygotes). Values for asymptomatic and symptomatic heterozygotes are significantly $(P<0.05)$ greater than control but not different from one another.

In Fig. 4 is shown the absolute concentration of plasma [5$\left.{ }^{15} \mathrm{~N}\right]$ glutamine $(\mu \mathrm{M})$. The concentration of $\left[5{ }^{-15} \mathrm{~N}\right]$ glutamine in both groups of heterozygotes at all time points exceeded that of the controls. The peak value in asymptomatic heterozygotes was $63.3 \pm 28.9 \mu \mathrm{M}$, or approximately three times the control

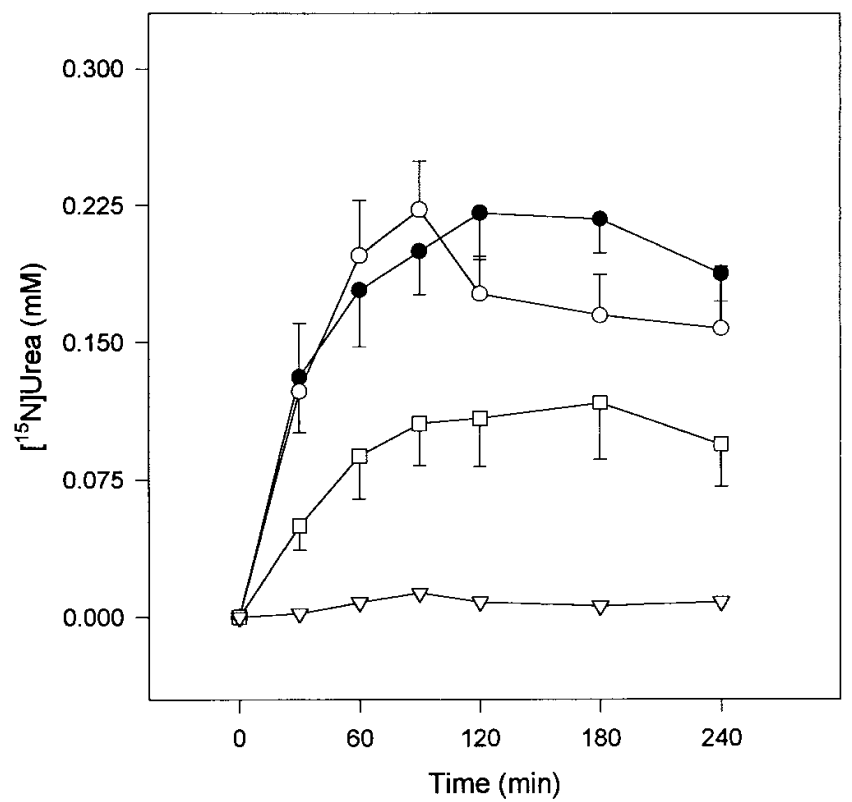

Figure 2. The absolute concentration $(\mathrm{mM})$ of $\left[{ }^{15} \mathrm{~N}\right]$ urea in the blood of controls, asymptomatic OTCD heterozygotes, symptomatic heterozygotes and a hemizygous male with OTCD. The absolute concentration of $\left[{ }^{15} \mathrm{~N}\right]$ urea represents the product/100 of the total $\left({ }^{15} \mathrm{~N}+\right.$ ${ }^{14} \mathrm{~N}$ ) urea concentration and the isotopic abundance (atom percent excess) (Fig. 1). Each point is the mean \pm SEM. Symbols as in Fig. 1.

value $(P<0.05)$. In symptomatic heterozygotes this parameter was $118.2 \pm 31.2 \mu \mathrm{M}$, or nearly 6 times the control value $(P<$ $0.05)$. The symptomatic and asymptomatic groups did not significantly differ from one another.

The cumulative appearance of label in plasma $\left[5-{ }^{15} \mathrm{~N}\right] \mathrm{glu}-$ tamine $(\mu \mathrm{M} \times 30 \mathrm{~min})$ was $( \pm \mathrm{SEM}): 2720 \pm 460$ (control), $8600 \pm 1290$ (asymptomatic heterozygotes) and $4740 \pm 1340$ (symptomatic heterozygotes). Both groups of carriers are significantly $(P<0.05)$ greater than control. The carrier groups did not differ from one another.

Effects of phenylbutyrate. At the time of study, several symptomatic heterozygotes were receiving sodium phenylbutyrate as prophylaxis against hyperammonemia. Although the amount of nitrogen administered as ${ }^{15} \mathrm{NH}_{4} \mathrm{Cl}$ was relatively small, ethical considerations precluded stopping this medication on the day of study. The possibility therefore existed that the diminished rate of $\left[{ }^{15} \mathrm{~N}\right]$ urea production observed in symptomatic heterozygotes (Figs. 1 and 2) might be an artifact caused by medication rather than a true reflection of compromised ureagenesis.

In order to assess the putative effect of phenylbutyrate therapy on $\left[{ }^{15} \mathrm{~N}\right]$ urea formation, we repeated the ${ }^{15} \mathrm{NH}_{4} \mathrm{Cl}$ loading study in four control females who took 4 grams of sodium phenylbutyrate (equivalent to a dose of $250 \mathrm{mg} / \mathrm{kg} / \mathrm{day}$ in four divided doses) before administration of the labeled ammonia. The basal (T0) urea concentration was $4.3 \pm 0.2 \mathrm{mM}$ before phenylbutyrate administration and $4.7 \pm 0.4 \mathrm{mM}$ afterwards $(P>0.05$ with paired $t$ test). The mean baseline blood glutamine concentration in this group $( \pm$ SEM) was $328.0 \pm$ $92.2 \mu \mathrm{M}$ prior to treatment and $463.3 \pm 57.7 \mu \mathrm{M}$ after treatment $(P>0.05)$. The cumulative appearance of label in $\left[{ }^{15} \mathrm{~N}\right]$ urea $(\mathrm{mM} \times 30 \mathrm{~min})$ was $( \pm \mathrm{SEM}): 1.23 \pm 0.11$ before ad- 


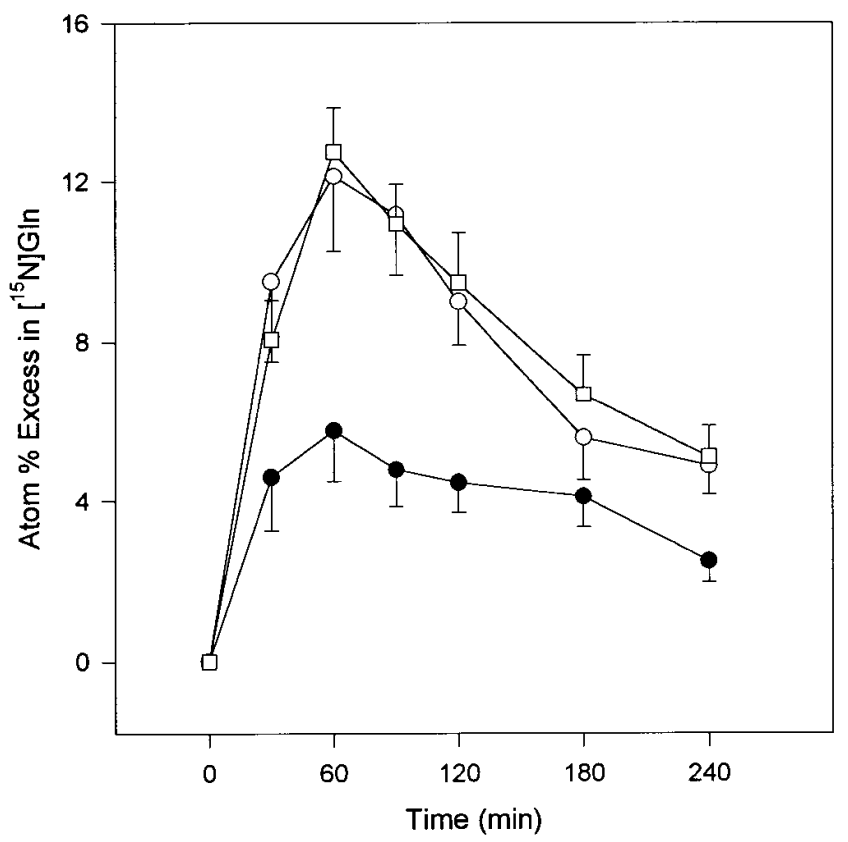

Figure 3. Isotopic abundance (atom percent excess) in $\left[5-{ }^{15} \mathrm{~N}\right]$ glutamine following the oral administration of a ${ }^{15} \mathrm{NH}_{4} \mathrm{Cl}$ load. Subjects included controls, asymptomatic OTCD heterozygotes and symptomatic heterozygotes. Each point is the mean \pm SEM. Symbols as in Fig. 1 .

ministration of phenylbutyrate and $1.01 \pm 0.05$ afterwards. A paired $t$ test showed no significant differences in the area under the curve $(P=0.12)$ when the pre- and post-phenylbutyrate data are compared. Mean cumulative appearance of la-

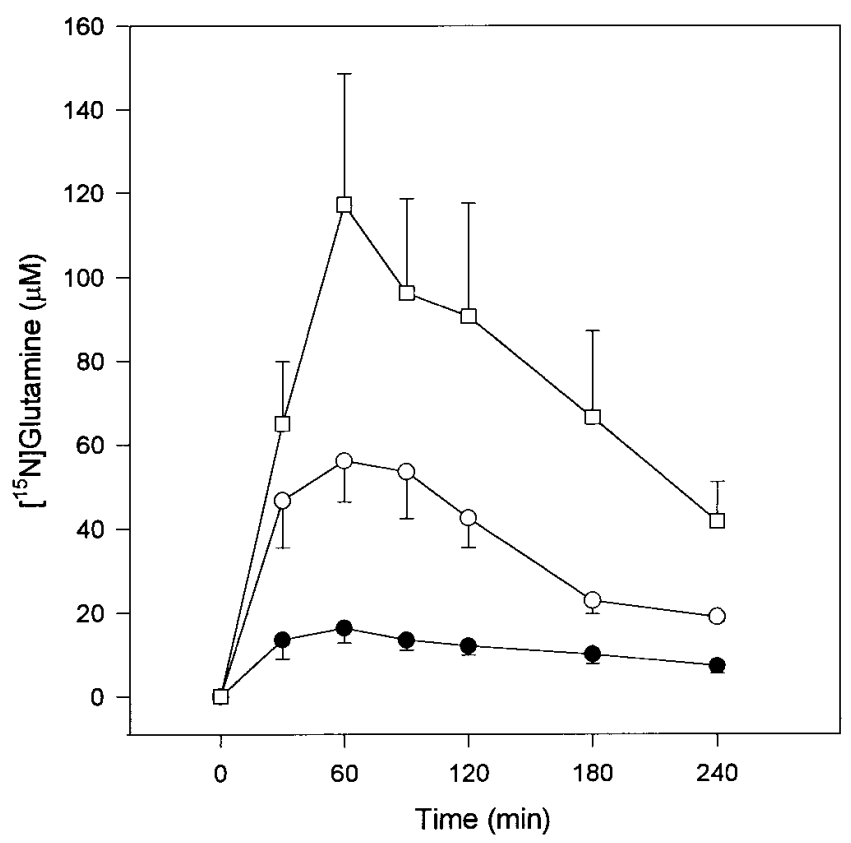

Figure 4. The absolute concentration $(\mu \mathrm{M})$ of $\left[5-{ }^{15} \mathrm{~N}\right]$ glutamine in the blood of the controls, asymptomatic OTCD heterozygotes and symptomatic heterozygotes. The absolute concentration of $\left[5-{ }^{-15} \mathrm{~N}\right]$ glutamine corresponds to the product $/ 100$ of the total $\left({ }^{15} \mathrm{~N}+{ }^{14} \mathrm{~N}\right)$ glutamine concentration and the isotopic abundance (atom percent excess) (Fig. 3). Symbols as in Fig. 1. bel in $\left[5-{ }^{15} \mathrm{~N}\right]$ glutamine $(\mu \mathrm{M} \times 30 \mathrm{~min})$ was $( \pm \mathrm{SEM}): 76.9 \pm$ 26.2 with phenylbutyrate treatment and $85.0 \pm 17.6$ afterwards $(P=0.63)$. Thus, the data show no consistent effect of phenylbutyrate therapy on the incorporation of the ${ }^{15} \mathrm{~N}$ label into either urea or glutamine.

A similar comparison of the peak value in either $\left[{ }^{15} \mathrm{~N}\right]$ urea or $\left[5-{ }^{15} \mathrm{~N}\right]$ glutamine also failed to reveal any significant effect of sodium phenylbutyrate therapy on ${ }^{15} \mathrm{~N}$ transfer to either urea or glutamine.

\section{Discussion}

The above data suggest the following. (a) The rate of ureagenesis in asymptomatic OTCD heterozygotes is comparable to that of a control population. (b) Symptomatic heterozygotes form demonstrably less urea than do controls. (c) Asymptomatic carriers may produce urea at the control rate, but their ammonia metabolism is not completely normal. This is manifested by an increased transfer of ${ }^{15} \mathrm{~N}$ into the amide group of glutamine. $(d)$ The foregoing results did not appear to be artifacts of sodium phenylbutyrate therapy, although it is possible that the isotopic method may have failed to detect a subtle diminution of ureagenesis.

The maximal plasma $\left[{ }^{15} \mathrm{~N}\right]$ urea concentration in controls (Fig. 2) was $0.221 \mathrm{mM}$. Because the duration of experimental observation is short compared with the turnover of body urea $(6,22)$, essentially all this urea must have been synthesized de novo rather than having been recycled. If we assume a urea distribution space of $40 \%$ of body weight, then $\sim 46 \%$ of the ${ }^{15} \mathrm{NH}_{4} \mathrm{Cl}$ dose was converted to urea during the $2 \mathrm{~h}$ after administration of the isotope (see Methods for details of calculation). This value is comparable with that recorded by Patterson et al. (9), who found that $\sim 50 \%$ of orally or parenterally administered ${ }^{15} \mathrm{NH}_{3}$ was converted into urea, with most of the remaining ${ }^{15} \mathrm{~N}$ resident in blood amino acids, particularly glutamine. Stone et al. (23) found that healthy adult males excreted from $50-80 \%$ of a ${ }^{15} \mathrm{~N}$-ammonium lactate load as $\left[{ }^{15} \mathrm{~N}\right]$ urea over a $3-\mathrm{d}$ period of experimental observation. Our observed rate of ureagenesis therefore is comparable to the results of other investigations.

The rate of $\left[{ }^{15} \mathrm{~N}\right]$ urea production in the asymptomatic carriers was similar to that of the control population (Fig. 2). Because of random inactivation of the $\mathrm{X}$ chromosome, female carriers for a sex-linked disorder such as OTC deficiency manifest a broad spectrum of phenotypes $(24,25)$. Most remain asymptomatic, but even ostensibly "silent" carriers sometimes develop hyperammonemia during a period of stress (26). Our observation of a normal rate of ureagenesis in asymptomatic heterozygotes is consistent with this epidemiology and indicates that a partial enzymatic deficiency is compatible with a reasonable capacity to detoxify ammonia.

It is difficult to determine precisely the minimal OTC enzyme activity that is compatible with normal ureagenesis. Studies in males with late-onset OTCD suggest that ureagenesis can be near normal with as little as $\sim 15 \%$ of normal hepatic enzyme activity $(27,28)$, although it must be emphasized that this figure represents overall hepatic activity and ignores the fact that urea cycle enzyme activity is not evenly distributed within the liver but is much greater in the peri-portal hepatocytes. This problem is of more than academic interest. Although the mainstay of the treatment of OTCD has been a 
combination of dietary protein restriction and alternate pathway therapy $(25,29)$, recent studies suggest the feasibility of viral-mediated transduction of affected hepatocytes with a cDNA for the OTC gene $(10,11,13,14)$. An implication of the current data is that efficacious gene therapy need not restore OTC activity to the control level in all liver cells. A favorable clinical response should occur even if overall enzyme activity is restored to a lower value.

Although these "silent" carriers may have a normal rate of ureagenesis, their overall nitrogen metabolism is still abnormal. This is reflected in the finding (Figs. 3 and 4) that all heterozygotes formed more $\left[5-{ }^{15} \mathrm{~N}\right]$ glutamine than did unaffected women (Figs. 3 and 4). Glutamine, the most abundant amino acid in the blood, also is a major repository of ammonia nitrogen (9), and an increased blood glutamine concentration often is a harbinger of hyperammonemia. Indeed, increased levels of glutamine in the brain may contribute to hyperammonemic encephalopathy (30). Ammonia nitrogen is transferred to glutamine and other amino acids before it is incorporated into urea, in which form this nitrogen is excreted (9).

The relatively high rate of glutamine synthesis differentiated ostensibly asymptomatic heterozygotes from controls. Indeed, the rise of blood $\left[5-{ }^{15} \mathrm{~N}\right]$ glutamine appeared to reflect gene-dosage, since this parameter was higher in asymptomatic OTCD heterozygotes than in controls and greater yet in symptomatic carriers (Figs. 3 and 4). The greatest enrichment (atom percent excess) was observed in the most profoundly affected subject, i.e., the boy with neonatal onset disease, although the combination of severe protein restriction and intensive acylation therapy so reduced his total blood glutamine concentration that the absolute level of $\left[5-{ }^{15} \mathrm{~N}\right]$ glutamine was less than that of the female heterozygotes (data not shown).

A practical application of the current protocol might be to monitor the response to enzyme enhancement by either orthotopic liver transplantation (12) or viral-mediated gene transfer $(10,11,13,14)$. The ${ }^{15} \mathrm{NH}_{4} \mathrm{Cl}$ loading procedure would afford several advantages as a monitoring instrument. (a) The test exposes the subject to no radioactivity or drugs. (b) The study design is simple and brief ( $\sim 4 \mathrm{~h})$ and the test is conveniently administered on an out-patient basis. (c) The amount of nitrogen administered $\left(\sim 5.45 \mathrm{mg} / \mathrm{kg}\right.$ as $\left.{ }^{15} \mathrm{NH}_{4} \mathrm{Cl}\right)$ is $<5 \%$ that which OTCD patients consume each day (1 gram protein $/ \mathrm{kg}$, or $\sim 160 \mathrm{mg}$ nitrogen $/ \mathrm{kg}$ ). The current procedure did not evoke hyperammonemia, even in affected patients. $(d)$ The test does not require the collection of urine, often an advantage when a young child or an individual with mental retardation is the subject of study. (e) The ${ }^{15} \mathrm{~N}$ tracer can safely be administered repeatedly, as long as labeling of either $\left[{ }^{15} \mathrm{~N}\right]$ urea or $\left[5-{ }^{15} \mathrm{~N}\right]$ glutamine has returned to a baseline value. $(f)$ The rate of $\left[{ }^{15} \mathrm{~N}\right]$ urea formation does not appear to be confounded by the administration of a modest dose $(250 \mathrm{mg} / \mathrm{kg}$ per day $)$ of sodium phenylbutyrate, although treatment with very high doses, e.g., $750 \mathrm{mg} / \mathrm{kg}$ per day, might divert sufficient ${ }^{15} \mathrm{~N}$ to reduce the rate of $\left[5-{ }^{15} \mathrm{~N}\right]$ glutamine or $\left[{ }^{15} \mathrm{~N}\right]$ urea appearance in blood. This problem presumably could be circumvented by withholding a single morning dose of the drug. $(g)$ The ${ }^{15} \mathrm{NH}_{4} \mathrm{Cl}$ load is a functional assay that permits the direct observation of nitrogen flux through the pathway which both gene therapy and liver transplantation are intended to rectify. In contrast, the allopurinol loading test (31), which measures the excretion of orotic acid and orotidine derived from a cytosolic pool of carbamyl phosphate, monitors a pathway of pyrimidine biosyn- thesis that is only indirectly influenced by metabolic events within the urea cycle itself. Gene therapy or immunosuppressive drugs well might alter flux through the pyrimidine pathway without ameliorating flux through the urea cycle, a phenomenon that the allopurinol challenge might fail to disclose (32). (h) The fact that the ${ }^{15} \mathrm{NH}_{4} \mathrm{Cl}$ loading procedure is a functional assay should mean that it would be an effective complement to mutational analysis of DNA, which is exquisitely specific but insufficiently sensitive to detect all cases (16).

\section{Acknowledgments}

This work was supported by grants NS-34900, NS-27889, HD-26979, HD-32649, and 5MO1-RR00240 from the National Institutes of Health.

\section{References}

1. Elsas, L.J., N.P. Ellerine, and P.D. Klein. 1993. Practical methods to estimate whole body leucine oxidation in maple syrup urine disease. Pediat. Res. 33:445-451.

2. Lehnert, W., W. Sperl, T. Suormala, and E.R. Baumgartner. 1994. Propionic acidaemia: clinical, biochemical and therapeutic aspects. Experience in 30 patients. Eur. J. Pediatr. 153(7 Suppl 1):S68-80.

3. Wareham, K.A., S. Howell, D. Williams, and E.D. Williams. 1983. Studies of X-chromosome inactivation with an improved histochemical technique for ornithine carbamyltransferase. Histochem. J. 15:363-371.

4. Batshaw, M.L., M. Msall, and J. Trojak. 1986. The risk of serious illness in carriers of ornithine transcarbamylase deficiency. J. Pediatr. 108:236-241.

5. Wolfe, R.R., R.D. Goodenough, J.F. Burke, and M.H. Wolfe. 1983. Response of protein and urea kinetics in burn patients to different levels of protein intake. Ann. Surg. 197:163-171.

6. Matthews, D.E., and P.S. Downey. 1984. Measurement of urea kinetics in humans: a validation of stable isotope tracer methods. Am. J. Physiol. 246: E519-E527.

7. Fomon, S.J., D.M. Bier, D.E. Matthews, R.R. Rogers, B.B. Edwards, E.E. Ziegler, and S.E. Nelson. 1988. Bioavailability of dietary urea nitrogen in the breast-fed infant. J. Pediatr. 113:515-517.

8. Dahms, W.T., R.P. Owens, S.C. Kalhan, D.S. Kerr, and R.K. Danish. 1989. Urea synthesis, nitrogen balance, and glucose turnover in growth-hormone-deficient children before and after growth hormone administration. Metab. Clin. Exp. 38:197-203.

9. Patterson, B.W., F. Carraro, S. Klein, and R.R. Wolfe. 1995. Quantification of incorporation of $\left[{ }^{15} \mathrm{~N}\right] \mathrm{ammonia}$ into plasma amino acids and urea. Am.J. Physiol. 269:E508-E515.

10. Grompe, M., S.N. Jones, H. Louseged, and T. Caskey. 1990. Retroviralmediated gene transfer of human ornithine transcarbamylase into primary hepatocytes of spf and spf-ash mice. Hum. Gene Ther. 3:35-44.

11. Stratford-Perricaudet, L.D., M. Levrero, M.-F. Chasse, M. Perricaudet, and P. Brian. 1990. Evaluation of the transfer and expression in mice of an enzyme-encoding gene using a human adenovirus vector. Hum. Gene Ther. 1:241256.

12. Todo, S., T.E. Starzl, A. Tzakis, K.J. Benkov, F. Kalousek, T. Saheki, K. Tanikawa and W.A. Fenton. 1992. Orthotopic liver transplantation for urea cycle enzyme deficiency. Hepatology. 15:419-422.

13. Morsy, M.A., E.L. Alford, A. Bett, F.L. Graham, and C.T. Caskey. 1993. Efficient adenoviral-mediated ornithine transcarbamylase expression in deficient mouse and human hepatocytes. J. Clin. Invest. 92:1590-1586.

14. Ye, X., M.B. Robinson, M.L. Batshaw, E.E. Furth, I. Smith, and J.M. Wilson. 1996. Prolonged metabolic correction in adult ornithine transcarbamylase-deficient mice with adenoviral vectors. J. Biol. Chem. In press.

15. Hauser, E.R., J.E. Finkelstein, D. Valle, and S.W. Brusilow. 1990. Allopurinol-induced orotindinuria. A test for mutations at the ornithine carbamoyltransferase locus in women. N. Engl. J. Med. 322:1641-1645.

16. Tuchman, M., R.A. Holzknecht, A.B. Gueron, S.A. Berry, and M.Y. Tsai. 1992. Six new mutations in the ornithine transcarbamylase gene detected by single-strand conformational polymorphism. Pediatr. Res. 32:600-604.

17. Brusilow, S.W., M. Danney, L.J. Waber, M.L. Batshaw, B. Burton, L. Levinsky, D. Roth, C. McKeethran, and J. Ward. 1984. Treatment of episodic hyperammonemia in children with inborn errors of urea synthesis. N. Engl. J. Med. 310:1630-1634.

18. Frederick, W.S., P.J. Berg, A.J.M. Miles, and M.W. Haymond. 1984. Use of t-butyldimethylsilylation in the GC-MS analysis of physiologic compounds found in the plasma using electron-impact ionization. Anal. Biochem. 141:101-109.

19. Jones, B.N., and T.P. Gilligan. 1983. o-phthalaldehyde precolumn derivatization and reversed-phase high performance liquid chromatography of polypeptide hydrolysates and physiologic fluids. J. Chromatogr. 266:471-482. 
20. Rosenblatt, J., D. Chinkes, M. Wolfe, and R.R. Wolfe. 1992. Stable isotope tracer analysis by GC-MS, including quantification of isotopomer effects. Am. J. Physiol. 263:E584-E596.

21. Dixon, W.J. 1992. BMDP Statistical Software. Berkeley, Univ. of California.

22. Long, C.L., M. Jeevanandam, and J.M. Kinney. 1978. Metabolism and recycling of urea in man. Am. J. Clin. Nutr. 31:1367-1382.

23. Stone, W.D., W.B.M. Gay, and C.W. Crane. 1969. The metabolism of ammonia in liver disease: urinary studies following oral doses of ${ }^{15} \mathrm{~N}$-ammonium lactate. Clin. Sci. 37:231-242.

24. Rowe, P.C., S.L. Newman, and S.W. Brusilow. 1986. Natural history of symptomatic partial ornithine transcarbamylase deficiency. N. Engl. J. Med. 314:541-547.

25. Batshaw, M.L. 1994. Inborn errors of urea synthesis. Ann. Neurol. 35: $133-141$

26. Arn, P.H., E.R. Hauser, G.H. Thomas, G. Herman, D. Hess, and S.W. Brusilow. 1990. Hyperammonemia in women with a mutation at the ornithine carbamoyltransferase locus. N. Engl. J. Med. 322:1652-1655.

27. Matsuda, I., N. Nagata, T. Matsuura, K. Oyanagi, K. Tada, K. Narisawa,
T. Kitagawa, T. Sakiyama, F. Yamashita, and M. Yoshino. 1991. Retrospective survey of urea cycle disorders. Part 1 . Clinical and laboratory observations of thirty-two Japanese male patients with ornithine transcarbamylase deficiency. Am. J. Med. Genet. 38:85-89.

28. Yudkoff, M., W. Yang, P.J. Snodgrass, and S. Segal. 1980. Ornithine transcarbamylase deficiency in a male with normal development. J. Pediatr. 96 441-443.

29. Brusilow, S.W., J. Tinker, and M.L. Batshaw. 1980. Amino acid acylation: a mechanism of nitrogen excretion in inborn errors of urea synthesis. Science (Wash. DC). 207:659-661.

30. Takahashi, H., R.C. Koehler, S.W. Brusilow, and R.J. Traystman. 1991. Inhibition of brain glutamine accumulation prevents cerebral edema in hyperammonemic rats. Am. J. Physiol. 261:H825-H829.

31. Burlina, A.B., V. Ferrari, C. Dionisi-Vici, A. Bordugo, F. Zacchello, and M. Tuchman. 1992. Allopurinol challenge test in children. J. Inher. Metab. Dis. 15:707-712.

32. Robinson, M.B., M.L. Batshaw, X. Ye, and J.M. Wilson. 1995. Prospects for gene therapy in ornithine carbamoyltransferase deficiency and other urea cycle disorders. Ment. Retard. Dev. Disabil. 1:62-70. 